\title{
Levels of ground corn supplied to beef heifers at pasture during the rainy season: productive performance, intake, digestibility and microbial efficiency $^{1}$
}

\section{Darcilene Maria de Figueiredoㄹ, Mário Fonseca Paulino ${ }^{3}$, Maykel Frankiln Lima Sales ${ }^{2}$, Sebastião de Campos Valadares Filho ${ }^{3}$, Edenio Detmann ${ }^{3}$, Lívia Vieira de Barros ${ }^{2}$}

\footnotetext{
1 Pesquisa financiada pelo CNPq e pela FAPEMIG.

2 Programa de Pós-graduação em Zootecnia - UFV, Viçosa, MG.

${ }^{3}$ Departamento de Zootecnia - UFV, Viçosa, MG.
}

ABSTRACT - The objective was to evaluate the effect of four levels of ground corn supply on nutritional parameters, microbial synthesis efficiency and growing performance of beef heifers, at the rainy season. For such, 28 crossbred yearling heifers, with initial age of 16-17 months and initial weight of $255 \pm 31.0 \mathrm{~kg}$ were distributed into five paddoks of B. decumbens, of 2.0 ha each, with average potentially digestible DM availability of 2,377.0 kg/ha. For each one of the lots, one of the following supplements was daily supplied: mineral mix exclusively or with ground corn at levels $0.25,0.50,0.75$ or $1.00 \mathrm{~kg} / \mathrm{day}$. The experiment was arranged in completely randomized design with five treatments (supplements), five repetitions for the groups receiving exclusive mineral mix or mineral mix plus corn on the level of $0.50 \mathrm{~kg} / \mathrm{day}$ and six repetitions for those receiving the other supplements. There was a response of $0.092 \mathrm{~kg}$ of weight gain for every $1 \mathrm{~kg}$ of ground corn supplied to the animals, and no substitution effect was verified on the dry matter intake of pasture. The increase in ground corn levels increased metabolizable energy intake, which is explained by the crescent linear effect on digestible dry matter intake, on apparent digestibility of dry matter and organic matter as well as on the levels of total digestible nutrients of the diet consistent with the increase in intake of the most digestible ingredient, ground corn. In the same way, there was a positive linear effect for apparent digestibility of neutral detergent fiber. The supplementation provided linear positive effect on the flow of microbial nitrogen compounds (MICN) for the small intestine, and did not affect the microbial synthesis efficiency. The supply of energetic supplement for beef heifers, at pasture, during the rainy season increases the use of the forage and consequently, weight gain.

Key Words: females, nutritional parameters, supplementation, synthesis of microbial protein, weight gain

\section{Introduction}

In the rainy season, pastures provide high protein degradability (McLennam \& Poppi, 1995), which can cause increases in $\mathrm{N}$ loss by the animal in the form of urea, because of the low energy content of high degradability (Detmann et al., 2005), resulting in a protein deficit in relation to requirements for high yields. Thus, when weight gain does not reach the level dictated by the animal's genetic potential, feed supplement is applied during the rainy season (Paulino et al., 2001).

Concerning energy supplements, it is worth underscoring the importance of the substitution effect because, generally, supplemental feeding on pasture quality results in reduced consumption of herbage by the animal, with increasing participation of the concentrate (Euclides \& Medeiros, 2005). Two hypotheses could explain the reduction in herbage intake. The first would be the consequence of associative effect between the pasture and concentrate, and the other would result in reduction of grazing period (Bargo et al., 2003). To avoid the effect of substitution, supplementation during the rainy season should be used to correct specific nutrients deficient in the forage.

The adequacy of energy sources used in the formulation of the supplement (starchy or fibrous) is of fundamental importance. This is because interactions between sources and amount of carbohydrates consumed and the characteristics of the pasture can also be harmful or beneficial to capture the energy from the fibrous carbohydrate of forage by rumen microorganisms. These interactions may be more associated with "carbohydrate effect" (Mould et al. 1983; Arroquy et al., 2005). The effect of carbohydrate observed with the addition of starch seems to involve competition for nutrients between microbial groups, resulting in greater proliferation of microorganisms that degrade starch (El-Shazly et al. 1961; Mould et al., 1983). According to El-Shazly et al. (1961), this effect is more pronounced in environments with ruminal nitrogen compounds deficiency. 
To better describe the impact of energy supplementation on forage utilization by grazing cattle, this research aimed to evaluate the effects of increasing levels of supply of maize grain on performance, intake and digestibility of nutrients and microbial synthesis efficiency of crossbred beef heifers reared in tropical pasture, in the rainy season.

\section{Material and Methods}

The experiment was conducted at the Setor de Bovinocultura de Corte of Departamento de Zootecnia in the Universidade Federal Viçosa, located in Viçosa, Minas Gerais, Brazil, between December 2005 and March 2006, during the rainy season.

Twenty-eight crossbred Holstein $\times$ Zebu and Zebu heifers, with initial ages of 16-17 months and average weight of $255 \pm 31 \mathrm{~kg}$ were used. In the pre-experimental period animals were treated against ecto and endoparasites, using a product based on abamectin. During the experimental period, animals were treated against infestation of ticks, horn flies and endoparasites.

Animals were distributed into five lots, and each group of animals received one of the following amounts of corn that constituted the supplements (Table 1): only mineral mix, mineral mix $+0.25 \mathrm{~kg}$ corn $/$ day, mineral mix $+0.50 \mathrm{~kg}$ corn $/$ day, mineral mix $+0.75 \mathrm{~kg}$ corn $/$ day, mineral mix $+1.00 \mathrm{~kg}$ corn $/$ day .

The experimental area for the animals consisted of five paddocks of B. decumbens, in a 2.0-ha area. Each paddock had troughs and trough cover for the distribution of the supplement. During the experimental periods, fixed stocking rate was applied by varying the charge by increasing only weight of animals.

Supplements were fed to the animals daily obeying the 10:30 h treatment.Animals had free access to water throughout the experiment. Even with the inclusion of mineral mix in the supplement, it was provided ad libitum on the corner of each trough. Samples of corn were collected during the experiment, amounting to a final composite sample for further laboratory analysis.
The experiment was divided in three periods of 28 days, totaling 84 days. In the end of each period, animals were weighed to monitor weight gain. Daily weight gain was obtained by the difference between initial weight and final weight divided by the number of days of assessment.

To estimate the total availability of forage available to animals, pasture samples were taken every 28 days by cutting it close to the ground in four areas randomly within each experimental paddock, using metallic square of $0.5 \times 0.5 \mathrm{~m}$ (McMeniman, 1997). After weighing, samples were homogenized by paddock and period. From these composite samples of forage, an aliquot was dried in a forced ventilation oven $\left(60 \pm 5^{\circ} \mathrm{C} / 72 \mathrm{~h}\right)$, ground in Willey type mill $(1.0 \mathrm{~mm})$ and stored for later laboratory analysis. In these samples, the percentage of potentially digestible DM (pdDM) offered to the animals was calculated. This result was obtained through in situ incubation of samples for 264 hours. After previous incubation of the samples, determined indigestible NDF (NDFi) in the residues was obtained after treatment with neutral detergent. To determine the pdDM, the equation (Paulino et al., 2006): $\mathrm{pdDM}=0.98 \times(100-\mathrm{NDF})+(\mathrm{NDF}-$ iNDF) was used, where: $0.98=$ true digestibility of contents cell; NDF $=$ NDF values of the sample based on DM and $\mathrm{NDF} i=\mathrm{iNDF}$ based on DM.

Sampling of pasture consumed by the animals was carried out by manual simulation of grazing. This collection was performed by one person in order to avoid variations inherent to the form of collection of each researcher, made across the length of each paddock every 20 days. The samples were dried in forced ventilation oven $\left(60 \pm 5^{\circ} \mathrm{C} / 72 \mathrm{~h}\right)$, ground in Willey type mill $(1 \mathrm{~mm})$ and stored in polyethylene bottles at room temperature.

To evaluate the nutritional characteristics (intake and total digestibility of nutrients and microbial efficiency) a test of 10 days was performed using the same animals in the evaluation of performance, achieved during the period from April 19 to April 29, 2006. Sampling of pasture consumed by the animals during the test was carried out by manual simulation of grazing. This harvest was accomplished by a

Table 1 - Composition percentage of supplements based on natural matter

\begin{tabular}{|c|c|c|c|c|c|}
\hline \multirow[t]{2}{*}{ Ingredients $(\%)$} & \multicolumn{5}{|c|}{ Supplements } \\
\hline & $\begin{array}{l}\text { Mineral } \\
\operatorname{mix}\end{array}$ & $\begin{array}{c}\text { Mineral mix }+ \text { corn } \\
\text { at } 0.25 \mathrm{~kg} / \text { day }\end{array}$ & $\begin{array}{c}\text { Mineral mix }+ \text { corn } \\
\text { at } 0.50 \mathrm{~kg} / \text { day }\end{array}$ & $\begin{array}{c}\text { Mineral mix }+ \text { corn } \\
\text { at } 0.75 \mathrm{~kg} / \text { day }\end{array}$ & $\begin{array}{c}\text { Mineral } \mathrm{mix}+\text { corn } \\
\text { at } 1.00 \mathrm{~kg} / \text { day }\end{array}$ \\
\hline Mineral $\operatorname{mix}^{1}(9 \%$ P) $\mathrm{kg} / \mathrm{animal} /$ day & 100.00 & 19.35 & 10.70 & 7.40 & 5.66 \\
\hline Ground corn grain $\mathrm{kg} / \mathrm{animal} /$ day & - & 80.65 & 89.30 & 92.60 & 94.34 \\
\hline$\% \mathrm{CP}^{2}$ supplied & 0.0 & 2.33 & 4.67 & 7.0 & 9.33 \\
\hline$\% \mathrm{TDN}^{2}$ supplied & 0.0 & 3.88 & 7.75 & 11.63 & 15.51 \\
\hline
\end{tabular}

${ }^{1}$ Composition: salt - 47.7\%; dicalcium phosphate - 50\%; zinc sulfate - $1.50 \%$; copper sulfate - $0.70 \%$; cobalt sulfate - $0.05 \%$; potassium iodate - $0.05 \%$.

2 Assuming a heifer of $300 \mathrm{~kg}$ of live weight with gain of $0.75 \mathrm{~kg} / \mathrm{day}$, the CP requirements are $757.4 \mathrm{~g} / \mathrm{day}$ and $4.59 \mathrm{~kg}$ of TDN/day, as recommended by Valadares Filho et al. (2006a,b,c).

$\mathrm{CP}=$ crude protein $; \mathrm{TDN}=$ total digestible nutrients 
single person in the entire length of each picket in the fourth and ninth days of trial, being processed in the same way as the plucked samples mentioned above.

To estimate DM intake, chromic oxide external indicator was used to estimate fecal output, which was provided to the animals between the first and ninth days of experimental period in the amount of $10.0 \mathrm{~g} / \mathrm{animal} / \mathrm{day}$. The external indicator was wrapped in paper and inserted directly into the esophagus, at 12:00 hours, with the aid of an applicator of PVC.

Feces samples were collected between the $8^{\text {th }}$ and $10^{\text {th }}$ days, followed by pre-established times: the eighth day $(16: 00 \mathrm{~h})$, the ninth day $(12: 00 \mathrm{~h}), 10^{\text {th }}$ day $(08: 00 \mathrm{~h})$. After drying in a forced ventilation oven $\left(60 \pm 5^{\circ} \mathrm{C} / 72 \mathrm{~h}\right)$, and grounded in a Willey type mill $(1 \mathrm{~mm})$, samples on different sampling times made up a composite sample, drawn on the dry weight for each animal. Estimates of fecal excretion of DM were obtained based on the ratio between the quantity supplied and the indicator concentration in feces.

On the $10^{\text {th }}$ day of the test spot urine samples were collected by spontaneous voiding, approximately four hours after delivery of supplement. $10 \mathrm{~mL}$ of these samples were diluted in $40 \mathrm{~mL}^{\circ} \mathrm{H}_{2} \mathrm{SO}_{4} 0.036 \mathrm{~N}$ and frozen $\left(-20{ }^{\circ} \mathrm{C}\right)$ for later determination of levels of creatinine, urea and purine derivatives (Valadares et al., 1999). Likewise, undiluted urine samples were frozen $\left(-20^{\circ} \mathrm{C}\right)$ for further analysis of total nitrogen.

Samples of the same day were taken by jugular vein puncture, also four hours after delivery of the supplement, using tubes and gel accelerator of coagulation, and centrifuged immediately. Serum was frozen $\left(-20^{\circ} \mathrm{C}\right)$ for subsequent quantification of urea.

All samples of consumed pasture and ground corn grain were examined for quantification of DM, OM, CP, EE and ash (AOAC, 1990). NDF was obtained according to Mertens (2002), without the use of sodium sulfite and using amylase (Termamyl 120 L, Novozymes). Ankom ${ }^{\circledR}$ system was used for evaluations of NDF, with modification of the bag used $(5.0 \times 5.0 \mathrm{~cm}, 100-\mu \mathrm{m}$ pore diameter $)$, which was made using non-woven fabric (TNT $-100 \mathrm{~g} / \mathrm{m}^{2}$ ). ADF, ADIN, NDIN and lignin (sulfuric acid 72\%) were obtained by sequential method of Robertson \& Van Soest (1981) and per protocol outlined by Licitra et al. (1996). NPN levels were determined as described by Licitra et al. (1996).

For quantification of the ADF (iADF), samples of processed food and feces were incubated in duplicate $\left(20 \mathrm{mg} \mathrm{DM} / \mathrm{cm}^{2}\right)$ in the rumen of two steers with rumen cannulas for 264 hours. After this period of incubation, the remaining material was subjected to extraction with acid detergent. Estimates of intake were obtained by fecal excretion and indigestibility ratio, using as internal indicator
iADF, according to the equation proposed by Detmann etal. (2001a): DMI (kg/day) $=\{[(\mathrm{EF} \times \mathrm{CIF})-\mathrm{IS}] / \mathrm{CIFO}\}+\mathrm{CMSS}$, where: $\mathrm{DMI}=\mathrm{DM}$ intake $(\mathrm{kg} /$ day $) \mathrm{EF}=$ fecal excretion $(\mathrm{kg} /$ day $), \mathrm{CIF}=$ concentration of indicator in feces $(\mathrm{kg} / \mathrm{kg})$, $\mathrm{SI}=$ indicator present in the supplement $(\mathrm{kg} / \mathrm{day}) ; \mathrm{CIFO}=$ concentration of indicator forage $(\mathrm{kg} / \mathrm{kg})$; and $\mathrm{CMSS}=\mathrm{DM}$ intake of supplement $(\mathrm{kg} /$ day) .

Feces samples from heifers were also submitted to analysis for quantification of DM, OM, CP, ash (AOAC, 1990) and NDF (Mertens, 2002). The non-fiber carbohydrates (NFC) were calculated according to Hall \& Akinyode (2000), using the formula:

$\mathrm{NFC}=100-[(\% \mathrm{CP}$ total $-\% \mathrm{~PB}$ urea $+\%$ urea $)+\% \mathrm{NDF}$ $+\% \mathrm{EE}+\% \mathrm{MM}]$.

To calculate the TDN, the following equation was used $(\mathrm{NRC}, 2001): \mathrm{TDN}=\mathrm{DCP}+(2.25 \mathrm{XDEE})+\mathrm{DcpNDF}+\mathrm{DNFC}$.

The concentrations of uric acid, creatinine, and urea in urine and serum were estimated by enzymatic colorimetric methods (Bioclin K052) modified Jaffé (Bioclin K016-1) and enzymatic colorimetric (Bioclin K047), respectively. In undiluted urine samples nitrogen content was also analyzed (Kjeldahl procedure). The levels of urinary allantoin were estimated by colorimetric methods (Chen \& Gomes, 1992). The conversion of urea nitrogen into urea was performed by multiplying the values obtained by the factor 0.466 .

The calculation of the daily urine volume was done using the relationship between the daily excretion of creatinine (CE) as a function of body weight (BW), and its concentration in spot urine samples, adopting the formula proposed by Chizzotti et al. (2006): CE $(\mathrm{mg} / \mathrm{kg})=32.27-0.01093 \times \mathrm{BW}$. Thus, the daily urinary excretion of nitrogen was the product of its concentration in the samples spot urine and estimated urine volume.

Total excretion of purine derivatives was calculated by the sum of allantoin and uric acid excreted in urine. Absorbed purines ( $\mathrm{Y}, \mathrm{mmol} / \mathrm{day})$ were calculated from the excretion of purine derivatives (X, mmol/day) via the equation: $Y=$ $\left(X-0.385 \mathrm{BW}{ }^{0.75}\right) / 0.85$, where: $0.85=$ purine absorbed recovery as purine derivatives and $0.385 P V^{0.75}=$ endogenous contribution to the excretion of purines (Verbic et al., 1990).

The synthesis of ruminal nitrogen ( $\mathrm{Y}, \mathrm{Nmic} \mathrm{g} / \mathrm{day}$ ) was calculated as the purines absorbed (X, mmol/day), using the equation described by Chen and Gomes (1992), except for the purine $\mathrm{N}$ total: $\mathrm{N}$ from bacteria relation of 0.134 , suggested by Valadares et al. (1999): $Y=70 X / 0.83 \times 0,134 \times 1000$, where: $70=\mathrm{N}$ content of purines $(\mathrm{mg} \mathrm{N} / \mathrm{mol})=0.134$ for purine $\mathrm{N}$ : total $\mathrm{N}$ in bacteria relation, and $0.83=$ coefficient of digestibility of bacterial purines. The microbial efficiency was expressed by unit: $g$ microbial $\mathrm{CP} / 100 \mathrm{~g}$ TDN consumed. 
The experiment was analyzed according to completely randomized design with five treatments (supplements), five replicates for the lots receiving supplements exclusive mineral mix and supplement $0.50 \mathrm{~kg} / \mathrm{day}$ and six repetitions for those receiving the other supplements, taking 0.10 as the critical level of probability of type I error. All statistical procedures were performed through the Statistical Analsys System (SAS, 1990). Due to the absence of cubic and quadratic effects on the levels of corn grain in diets, they were omitted from the results.

\section{Results and Discussion}

In this study, the percentages found for pdDM of the whole plant in relation to the total amount of DM (TDM) were $70.50,67.0$ and $67.74 \%$, respectively, for the first (January), second (in February) and third (March) periods. The average availability of TDM and pdDM during the experimental period were 3482.0 and $2377.0 \mathrm{~kg} / \mathrm{ha}$, respectively. The offer of pdDM pasture $4-5 \%$ of BW of the animals was considered, which, according to Paulino et al. (2002), is necessary for satisfactory performance of animals raised on pasture. Thus, the availability of TDM and pdDM for the animals as percentage of BW were $5.40 \%$ and $3.68 \%$, respectively. Although the supply of pdDM was below these recommendations, forage offer was greater than the supply of DM forage intake (\% BW) expected for Zebu in the tropics, which is approximately $2.13 \%$ of $\mathrm{BW}$, according Valadares Filho et al. (2006b).

B. decumbens derived from the plucking had $\mathrm{CP}$ content of $9.14 \%$ (Table 2 ), exceeding the minimum value of $7.0 \%$ in forage reported by Lazzarini et al. (2009), as necessary to facilitate the appropriate use of rumen microorganisms' basal forage. However, although the forage consumed by animals showed CP content higher than the minimum required, it was found that $46.34 \%$ of this protein were slowly available to the animal, i.e., in the form of NDIN, and $8.63 \%$ was in the form of NIDA (Table 2 ).

There was positive linear effect $(\mathrm{P}<0.10)$ of levels of corn on the performance of heifers (Table 3 ). The amount of $1.0 \mathrm{~kg} / \mathrm{animal} / \mathrm{day}$ of ground corn $(1.00 \mathrm{~kg} /$ day $)$ provided the animals in this group, average daily gain $17.04 \%$ higher than the gains made by animals fed mineral mix exclusively.

Ruminal variables such as passage rate, $\mathrm{pH}$ and levels of nitrogen available to microbiota will affect the digestion of any food in particular (Van Barneveld, 1999). Thus, the relative nutritive value of cereal grain depends on its proportion in the total diet, its degree of processing, other dietary constituents and the level of productivity of the herd.

The animals' response to forage intake in relation to muscle growth, fat deposition or growth of fiber depends on the amount and balance of nutrients absorbed (Poppi et al., 1997). Thus, the gain with the inclusion of corn may have been a consequence of the associative effect between forage quantity and type of concentrate offered.

Porto (2005) evaluated the effect of providing $1 \mathrm{~kg} /$ animal/day supplement of corn in different forms on the performance of steers in the finishing phase, during the rainy season. This author found no effect of supplementation on performance; however, the use of multiple supplements based on cracked corn cob provided weight gain increase

Table 2 - Chemical composition of ground corn and Brachiaria decumbens

\begin{tabular}{|c|c|c|c|}
\hline \multirow[t]{2}{*}{ Item } & \multirow[t]{2}{*}{ Ground corn } & \multicolumn{2}{|c|}{ B. decumbens } \\
\hline & & 2 & 3 \\
\hline Dry matter (\% natural matter) & 87.38 & $28.68 \pm 1.04^{4}$ & $28.39 \pm 0.09$ \\
\hline Organic matter $(\%$ DM $)$ & 98.83 & $90.54 \pm 1.00$ & $90.62 \pm 0.10$ \\
\hline Crude protein $(\%$ DM) & 8.09 & $9.14 \pm 2.03$ & $10.10 \pm 1.02$ \\
\hline NDIN $(\% \text { total } N)^{1}$ & 14.23 & $46.34 \pm 12.37$ & $44.06 \pm 2.81$ \\
\hline $\operatorname{ADIN}(\% \text { total } \mathrm{N})^{1}$ & 4.41 & $8.63 \pm 2.19$ & $7.74 \pm 1.78$ \\
\hline $\mathrm{NPN}(\% \text { total } \mathrm{N})^{1}$ & 16.50 & $27.45 \pm 4.37$ & $34.31 \pm 3.85$ \\
\hline Ether extract ( $\%$ DM) & 3.47 & $1.99 \pm 0.53$ & $1.66 \pm 0.11$ \\
\hline $\mathrm{NDF}(\% \quad \mathrm{DM})^{1}$ & 15.98 & $70.87 \pm 1.39$ & $70.49 \pm 0.85$ \\
\hline pNDF $(\% \quad D M)^{1}$ & 12.04 & $66.39 \pm 3.61$ & $66.03 \pm 0.29$ \\
\hline Non-fibrous carbohydrate (\% DM) & 71.29 & $9.08 \pm 0.38$ & $8.37 \pm 1.86$ \\
\hline Acid detergent fiber (\% DM) & 4.05 & $32.14 \pm 2.99$ & $29.48 \pm 0.32$ \\
\hline Lignin $(\% \mathrm{DM})$ & 1.16 & $3.74 \pm 0.78$ & $3.08 \pm 0.07$ \\
\hline iNDF $(\% \text { DM })^{1}$ & 2.06 & $24.50 \pm 1.69$ & $22.13 \pm 0.37$ \\
\hline $\mathrm{iADF}(\% \mathrm{DM})^{1}$ & 0.64 & $11.68 \pm 1.12$ & $11.35 \pm 0.33$ \\
\hline
\end{tabular}

${ }^{1} \mathrm{NDIN}=$ neutral detergent insoluble nitrogen; ADIN = acid detergent insoluble nitrogen; NPN = non-protein nitrogen; NDF = neutral detergent fiber; $\mathrm{pNDF}=\mathrm{NDF}$ correct for protein; iNDF = indigestible neutral detergent fiber; iADF = indigestible acid detergent fiber.

2 Sample plucking.

${ }^{3}$ Sample plucked during the trial of nutritional characteristics.

${ }^{4}$ Standard deviation of the mean. 
of $165 \mathrm{~g}$ /animal compared with the control (mineral mixture). In this study, there was response of $0.092 \mathrm{~kg}$ of weight gain for every $1 \mathrm{~kg}$ of corn supplied to the animals (Table 3 ). In this case, the decision for supplementation with corn will depend on other factors such as price of inputs, price paid for the arroba of the heifer ready to be covered, the proximity of the breeding season and the need for evacuation of grazing land.

Linear effect was positive $(\mathrm{P}<0.10)$ for average consumption (kg/day) of EE, NFC, TDN, DM digested and TDN in \% BW. Digested DM intake (dDMI) provides a measure of digestibility and consumption which, in practice, represents the digestible energy intake being directly related to the weight gain estimated (Fieser \& Vanzant, 2004), the same feature represented by TDN intake (Table 4).

At supplementation, when there is no nutritional limitation (Poppi et al., 1987) to forage intake (availability, access, pasture height), the higher quality roughages are replaced by the supplement in quantities larger than those of lower quality (Moore et al., 1999). This same author notes that, for roughages whose voluntary intake of NDF is below the $1.75 \% \mathrm{BW}$, no substitution occurs with depression, thus corroborating the behavior of consumption observed in the supplementations of this study (Table 4).

Porto (2005) found a substitutive effect on forage intake of steers fed supplements when supplied with corn

Table 3 - Supplement and protein intake, initial and final body weight $(\mathrm{kg})$ and average daily gain $(\mathrm{kg} /$ day) for heifers at pasture receiving supplementation with ground corn

\begin{tabular}{|c|c|c|c|c|c|c|c|c|c|c|c|c|}
\hline \multirow[t]{2}{*}{ Item $^{2}$} & \multicolumn{5}{|c|}{$\begin{array}{l}\text { Level of corn } \\
\text { in the supplement }\end{array}$} & \multicolumn{2}{|c|}{$\mathrm{P}$ value ${ }^{1}$} & \multirow[t]{2}{*}{ CV $(\%)$} & \multicolumn{3}{|c|}{$\begin{array}{l}\text { Estimates of } \\
\text { regression parameters }\end{array}$} & \multirow[t]{2}{*}{$\mathrm{r}^{2} / \mathrm{R}^{2}$} \\
\hline & $\begin{array}{l}\text { Mineral } \\
\text { Mix }\end{array}$ & $\begin{array}{c}0.25 \\
\mathrm{~kg} / \text { day }\end{array}$ & $\begin{array}{c}0.50 \\
\mathrm{~kg} / \text { day }\end{array}$ & $\begin{array}{c}0.75 \\
\mathrm{~kg} / \text { day }\end{array}$ & $\begin{array}{c}1.00 \\
\mathrm{~kg} / \text { day }\end{array}$ & $\mathrm{L}$ & Q & & $\mathrm{b}_{0}$ & $\mathrm{~b}_{1}$ & $\mathrm{~b}_{2}$ & \\
\hline Supplement intake $(\mathrm{kg})$ & 0.00 & 0.218 & 0.437 & 0.655 & 0.874 & - & - & - & - & - & - & - \\
\hline Intake CP (kg) & 0.00 & 0.018 & 0.035 & 0.053 & 0.071 & - & - & - & - & - & - & - \\
\hline Initial BW (kg) & 257.9 & 254.40 & 239.50 & 266.70 & 259.50 & - & - & - & - & - & - & - \\
\hline
\end{tabular}

${ }^{1} \mathrm{~L}$ and $\mathrm{Q}=$ linear and quadratic effects for levels of ground corn grain in diets, respectively.

${ }^{2} \mathrm{CP}=$ crude protein; $\mathrm{BW}=$ body weight; $\mathrm{ADG}=$ average daily gain.

$\mathrm{CV}=$ coefficient of variation; $\mathrm{r}^{2} / \mathrm{R}^{2}=$ coefficient of determination for the regression model of quadratic order/coefficient of determination for the regression model of cubic order, respectively.

Table 4 - Nutrient intake of heifers on pasture receiving supplementation with ground corn

\begin{tabular}{|c|c|c|c|c|c|c|c|c|c|c|c|c|}
\hline \multirow[t]{2}{*}{ Item } & \multicolumn{5}{|c|}{$\begin{array}{l}\text { Level of corn } \\
\text { in the supplement }\end{array}$} & \multicolumn{2}{|c|}{$\mathrm{P}$ value $^{1}$} & \multirow[t]{2}{*}{ CV $(\%)$} & \multicolumn{3}{|c|}{$\begin{array}{l}\text { Estimates of } \\
\text { regression parameters }\end{array}$} & \multirow[t]{2}{*}{$\mathrm{r}^{2} / \mathrm{R}^{2}$} \\
\hline & $\begin{array}{l}\text { Mineral } \\
\operatorname{mix}\end{array}$ & $\begin{array}{c}0.25 \\
\mathrm{~kg} / \text { day }\end{array}$ & $\begin{array}{c}0.50 \\
\mathrm{~kg} / \text { day }\end{array}$ & $\begin{array}{c}0.75 \\
\mathrm{~kg} / \text { day }\end{array}$ & $\begin{array}{c}1.00 \\
\mathrm{~kg} / \text { day }\end{array}$ & $\mathrm{L}$ & Q & & $\mathrm{b}_{0}$ & $\mathrm{~b}_{1}$ & $\mathrm{~b}_{2}$ & \\
\hline & \multicolumn{11}{|c|}{$\mathrm{kg} / \mathrm{animal} /$ day } & \\
\hline Total dry matter & 6.326 & 6.614 & 6.175 & 7.232 & 7.063 & 0.1545 & 0.8026 & 16.0 & - & - & - & - \\
\hline Pasture dry matter & 6.326 & 6.395 & 5.738 & 6.577 & 6.190 & 0.9588 & 0.8023 & 17.1 & - & - & - & - \\
\hline Organic matter & 5.728 & 6.006 & 5.627 & 6.602 & 6.467 & 0.1209 & 0.8029 & 15.9 & - & - & - & - \\
\hline Pasture organic matter & 5.728 & 5.790 & 5.195 & 5.954 & 5.604 & 0.9583 & 0.8022 & 17.1 & - & - & - & - \\
\hline Crude protein & 0.578 & 0.602 & 0.559 & 0.658 & 0.636 & 0.2073 & 0.8038 & 16.1 & - & - & - & - \\
\hline $\begin{array}{l}\text { Neutral detergent } \\
\text { fiber (NDF) }\end{array}$ & 4.484 & 4.567 & 4.136 & 4.766 & 4.526 & 0.7747 & 0.8034 & 16.8 & - & - & - & - \\
\hline $\mathrm{pdNDF}^{2}$ & 2.934 & 2.997 & 2.722 & 3.142 & 2.992 & 0.6894 & 0.8024 & 17.8 & - & - & - & - \\
\hline Ether extract & 0.126 & 0.135 & 0.129 & 0.154 & 0.154 & 0.0157 & 0.7986 & 14.9 & 0.1248 & 0.0299 & - & 0.7888 \\
\hline Non-fibrous carbohydrate & 0.574 & 0.736 & 0.833 & 1.064 & 1.185 & 0.0001 & 0.8065 & 10.7 & 0.5697 & 0.6203 & - & 0.9868 \\
\hline Total digestible nutrients & 3.558 & 3.741 & 3.667 & 4.278 & 4.229 & 0.0339 & 0.8888 & 15.6 & 3.5235 & 0.7557 & - & 0.7381 \\
\hline Digestible dry matter & 3.634 & 3.772 & 3.715 & 4.353 & 4.270 & 0.0366 & 0.8671 & 15.4 & 3.5809 & 0.7480 & - & 0.7119 \\
\hline \multirow[t]{2}{*}{ dNDF } & 2.855 & 2.806 & 2.687 & 3.027 & 2.940 & 0.5304 & 0.6734 & 17.1 & - & - & - & - \\
\hline & \multicolumn{11}{|c|}{$\mathrm{g} / \mathrm{kg}$ liveweight } & \\
\hline Total dry matter & 20.5 & 21.8 & 21.7 & 22.7 & 21.8 & 0.2792 & 0.3624 & 10.0 & - & - & - & - \\
\hline Pasture dry matter & 20.5 & 21.1 & 20.1 & 20.6 & 19.1 & 0.2403 & 0.4380 & 10.8 & - & - & - & - \\
\hline Organic matter & 18.6 & 19.8 & 19.7 & 20.7 & 20.0 & 0.1988 & 0.3572 & 9.9 & - & - & - & - \\
\hline Pasture organic matter & 18.6 & 19.1 & 18.2 & 18.6 & 17.3 & 0.2405 & 0.4374 & 10.8 & - & - & - & - \\
\hline Neutral detergent fiber & 14.5 & 15.1 & 14.5 & 14.9 & 14.0 & 0.5008 & 0.4170 & 10.6 & - & - & - & - \\
\hline Total digestible nutrients & 11.6 & 12.4 & 12.8 & 13.4 & 13.1 & 0.0359 & 0.3336 & 10.3 & 11.8387 & 1.6128 & - & 0.7964 \\
\hline
\end{tabular}


in different physical forms in the amount of $1 \mathrm{~kg} / \mathrm{animal} /$ day . Knowledge of the substitutive effect has practical and economic implications (Minson, 1990); it is desirable that the use of supplements optimize the use of forage resources by the animal, instead of promoting its replacement as major phenomenon.

The absence of substitution effect $(\mathrm{P}>0.10)$ in pasture dry matter intake (Table 4 ) observed in this study with the inclusion of energy supplement may have been due to the low availability of green leaf DM $(1,078.7 \mathrm{~kg} / \mathrm{ha})$ since this availability was below the offer of $1,108 \mathrm{~kg} / \mathrm{ha}$, cited by Euclides et al. (1992), analyzing grazing B. decumbens, as not limiting to selection. This behavior can also be strenghtened by the use of TDN, which increased about $750 \mathrm{~g} / \mathrm{kg}$ of corn, which is near the TDN value of corn used in this study (81.46\% ofDM), calculated according to NRC (2001) (Table 4).

According to statements of Poppi \& McLennan (1995) increases in total DM intake would be expected through increased consumption of energy, which would tend to favor the retention of nitrogen by the animal. However, Detmann et al. (2001b), consistent with this study, also found no effects on total consumption, when providing supplements based on energy sources for animals grazing in the rainy season.

Unlike other variables related to daily intake, consumption of EE, non-fibrous carbohydrate (NFC), TDN and dDM were affected by supplementation and increased linearly $(\mathrm{P}<0.10)$ with increasing levels of corn in the diet (Table 4).To these effects, since no differences between supplements regarding the intake of pasture were observed $(\mathrm{P}>0.10)$, the composition of the supplement, whose digestible nutrients levels increased in proportion to the percentage of corn in each supplementis assigned as the sole and exclusive cause. Such behavior is consistent with reports of Poppi et al. (1997), who claimed that a simple way to modify the supply of NFC is to add supplements to the diet.

The increasing levels of corn provided an increasing linear response $(\mathrm{P}<0.10)$ for the coefficients of dry matter, organic matter and ether extract (Table 5). Not always is a change in intake accompanied by changes in digestibility and vice versa, as observed in this study with the effect of increasing levels of corn, since both were linearly increasing in intake (Table 4) as the coefficient of apparent digestibility of ether extract (Table 5) with no inverse relationships between intake and digestibility for all supplements.

Increased intake of metabolizable energy can be obtained by expanding the digestibility and/or OM intake (Poppi et al., 1987). In this sense, the increased levels of corn in the diet of heifers increased the metabolizable energy intake, this fact is evidenced by the increasing linear effect $(\mathrm{P}<0.10)$ in intake of dDM (Table 4$)$, the digestibility coefficients of total DM, organic matter and levels of TDN (Table 5). Opposite result was found in the study of Goestsch et al. (1991), in which there was depression in organic matter digestibility with increasing hay supplemented with ground corn, a depression of about 3.3 percentage points for each additional gram of corn.

There was a positive linear effect $(\mathrm{P}<0.10)$ for NDF digestibility with increasing ground corn intake by animals (Table 5). This effect is consistent with the arguments of Obara et al. (1991) and Poppi \& McLennan (1995), who reported the relevance of additional energy to the rumen when the animal is consuming forage growth with high content of nitrogen compounds readily available. These authors found that grazing animals, during the rainy season, may respond to increased protein supply, which could be obtained directly, with the use of supplements of protein nature, or indirectly by the use of energy supplements, which

Table 5 - Apparent total digestibility of nutrients in heifers at pasture receiving supplementation with ground corn

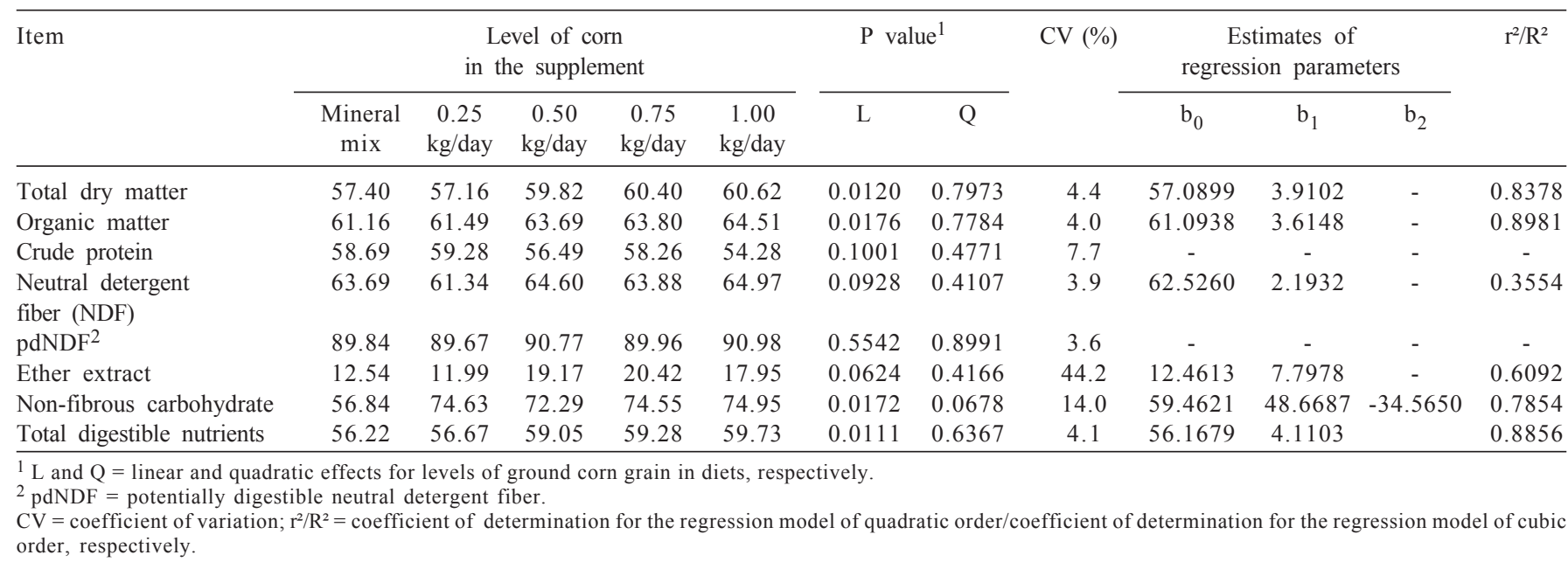


would assist in supplying protein to the animal, increasing the fixation of ammonia into microbial protein in the rumen. In this study, the supply of energy source probably contributed to better fixation of ammonia by microorganisms, which improved fiber digestibility in the rumen.

Quadratic order effect $(\mathrm{P}<0.10)$ of non-fibrous carbohydrate digestibility was observed with increasing levels of corn-supplied heifers (Table 5). The digestibility coefficient of the non-fibrous carbohydrate at mineral mix supply was $24.16 \%$ lower than supplement formulated with $1.00 \mathrm{~kg} / \mathrm{day}$, a possible consequence of true crude protein intake, which was numerically lower $(\mathrm{P}>0.10)$ in mineral mix supplement (Table 4), essential source nitrogen for growth of microorganisms that degrade non-fibrous carbohydrate, since they have additional requirements in terms of amino acids and peptides (Russell et al., 1992).

These effects of positive linear order observed for the level of TDN in diets in this study were consistent with the increased intake of the more digestible ingredient, corn, which had estimed $81.46 \%$ of TDN (Table 2 ).

The ruminal microbial activity is dependent on the level of ammoniacal nitrogen $(\mathrm{N})$ present in the medium (Detmann et al. 2001b). However, in seasons favorable to the growth of forage, high protein degradability can promote high levels of ammoniacal nitrogen, leading to heavy losses by diffusion (Poppi \& McLennan, 1995).

In these cases, a potential benefit of supplementation, particularly in forage grazed during the rainy season, is to increase the capture of available $\mathrm{N}$ in the rumen as microbial protein, with greater conversion of $\mathrm{N}$ into tissue (Fieser \& Vanzant, 2004), thereby reducing losses and rumen ammonia concentration (Poppi \& McLennan, 1995) and the use of amino acids for energy production.

In this study, positive linear order effect $(\mathrm{P}<0.10)$ was found on the flow of microbial nitrogen compounds (NMIC) to the small intestine of the heifers (Table 6). The supplement at $1.00 \mathrm{~kg}$ /day increased the production of NMIC in $15.75 \%$, compared with the mineral mix supplement. Sampaio (2007) pointed out that the variable NMIC partly reflects the increase in the intake of nitrogenous compounds. Thus, the aforementioned result could be reflecting the greater intake of CP provided by supplement at $1.00 \mathrm{~kg} /$ day compared with mineral mix exclusively; 0.636 and $0.578 \mathrm{~kg} / \mathrm{animal} / \mathrm{day}$, respectively.

The best production of NMIC in animals receiving $1.00 \mathrm{~kg} /$ day of ground corn supplement may have resulted in increments in weight gain (Table 3 ) and agrees with the statement of Fieser \& Vanzant (2004). There were nitrogen intake (IN) means lower than the production of NMIC (Table 6). This result is favorable, since IN $<$ NMIC indicates that most microbial demand for nitrogen compounds can be attributed to the recycling of urea ruminal inefficiently (Van Soest, 1994). The average NMIC in relation to nitrogen intake (RNMIC), despite not showing significant effect $(\mathrm{P}>0.10)$, was favorable to the supplement to $1.00 \mathrm{~kg} /$ day (Table 6). This fact, coupled with satisfactory microbial nitrogen production, indicates good fixation of nitrogen intake on microbial crude protein for the supplement and, is also consistent with the best gains in weight (Table 3) observed in animals receiving this $1.0 \mathrm{~kg}$ /day of corn.

Means were observed for microbial efficiency of heifers (Table 6), expressed as g CPmic/100g TDN consumed, lower

Table 6 - Flow of microbial nitrogen compounds, relative intestinal flow of microbial N, microbial efficiency synthesis, concentration serum urea nitrogen, intake of $\mathrm{N}$, urinary urea nitrogen excretion, apparent $\mathrm{N}$ balance and in relation to nitrogen intake in heifers at pasture receiving supplementation with ground corn

\begin{tabular}{|c|c|c|c|c|c|c|c|c|c|c|c|c|}
\hline \multirow[t]{2}{*}{ Item $^{2}$} & \multicolumn{5}{|c|}{$\begin{array}{l}\text { Level of corn } \\
\text { in the supplement }\end{array}$} & \multicolumn{2}{|c|}{$\mathrm{P}$ value $^{1}$} & \multirow[t]{2}{*}{ CV (\%) } & \multicolumn{3}{|c|}{$\begin{array}{c}\text { Estimates of } \\
\text { regression parameters }\end{array}$} & \multirow[t]{2}{*}{$\mathrm{r}^{2} / \mathrm{R}^{2}$} \\
\hline & $\begin{array}{l}\text { Mineral } \\
\operatorname{mix}\end{array}$ & $\begin{array}{c}0.25 \\
\mathrm{~kg} / \text { day }\end{array}$ & $\begin{array}{c}0.50 \\
\mathrm{~kg} / \text { day }\end{array}$ & $\begin{array}{c}0.75 \\
\mathrm{~kg} / \text { day }\end{array}$ & $\begin{array}{c}1.00 \\
\mathrm{~kg} / \text { day }\end{array}$ & $\mathrm{L}$ & Q & & $\mathrm{b}_{0}$ & $\mathrm{~b}_{1}$ & $\mathrm{~b}_{2}$ & \\
\hline NMIC & 63.60 & 64.11 & 65.79 & 70.08 & 73.65 & 0.0380 & 0.5621 & 13.3 & 62.1438 & 10.6168 & - & 0.9248 \\
\hline RNMIC & 0.688 & 0.673 & 0.730 & 0.669 & 0.730 & 0.5023 & 0.7559 & 13.1 & - & - & - & - \\
\hline EFIM & 11.27 & 10.74 & 11.18 & 10.21 & 10.90 & 0.5453 & 0.6229 & 13.8 & - & - & - & - \\
\hline NUS & 15.39 & 11.82 & 14.34 & 17.66 & 14.67 & 0.1805 & 0.7485 & 18.1 & - & - & - & - \\
\hline IN & 93.06 & 97.01 & 90.21 & 105.29 & 102.46 & 0.2052 & 0.8086 & 16.0 & - & - & - & - \\
\hline NUS/IN & 0.167 & 0.125 & 0.163 & 0.169 & 0.144 & 0.9349 & 0.9663 & 20.5 & - & - & - & - \\
\hline EUNU & 37.96 & 33.72 & 39.76 & 43.75 & 45.31 & 0.0756 & 0.5790 & 25.7 & 34.8523 & 10.3010 & - & 0.7265 \\
\hline $\mathrm{NB}$ & 39.31 & 47.73 & 44.74 & 54.84 & 49.05 & 0.1646 & 0.4390 & 28.1 & - & - & - & - \\
\hline RNB & 0.407 & 0.488 & 0.491 & 0.520 & 0.481 & 0.2150 & 0.1828 & 20.5 & - & - & - & - \\
\hline
\end{tabular}

${ }^{1} \mathrm{~L}$ and $\mathrm{Q}=$ linear and quadratic effects for levels of ground corn grain in diets, respectively.

${ }^{2} \mathrm{NMIC}=$ Flow of microbial nitrogen compounds $(\mathrm{g} / \mathrm{day}) ; \mathrm{RNMIC}=$ relative intestinal flow of microbial N $(\mathrm{g} / \mathrm{g} \mathrm{N}$ ingested $) ; \mathrm{EFIM}=$ microbial efficiency synthesis (g CPmic/100 g TDN ingested); NUS = concentration serum urea nitrogen (mg/dL); IN = intake of N (g/day); NUS/IN = NUS/IN ratio; EUNU = urinary urea nitrogen excretion (g/day); $\mathrm{NB}=$ apparent $\mathrm{N}$ balance ( $\mathrm{g} /$ day) and in relation to nitrogen intake (RNB).

$\mathrm{CV}=$ coefficient of variation; $\mathrm{r}^{2} / \mathrm{R}^{2}=$ coefficient of determination for the regression model of quadratic order/coefficient of determination for the regression model of cubic order, respectively. 
than the benchmark established in the NRC (2001), which is $13.0 \mathrm{~g} \mathrm{CP} / 100 \mathrm{~g}$ TDN, and also lower than the benchmark of $12.0 \mathrm{~g} \mathrm{CP} / 100 \mathrm{~g}$ NDT recommended by Valadares Filho et al. (2006a), the latter being more appropriately related to tropical conditions to which animals in Brazil are subject.

Both microbial efficiency (g CPmic/100g TDN) and the production of NMIC $14.01 \mathrm{gCP} / 100 \mathrm{~g}$ TDN and $116.54 \mathrm{~g} /$ day, respectively, verified by Porto (2005) were superior to these variables in this study. This superiority probably comes from the better formulation of the supplement, given that the author provided maize in different physical forms together with urea and cottonseed meal,providing calves with $22 \% \mathrm{CP}$. This certainly generates better harmony between nitrogen and energy, essential precursors to ensure better microbial enzyme activity (Paulino et al., 2006).

The variable in the serum urea nitrogen (NUS) is employed to diagnose the appropriateness of the use of nitrogen in the rumen to the availability of degradable organic matter (Sampaio, 2007). Considering the suggestion of Valadares et al. (1997) in which plasma urea levels between 13.52 and $15.15 \mathrm{mg} / \mathrm{dL}$ correspond to the maximum microbial efficiency and would probably be the limit at which there is loss of protein for Zebu steers fed a $62.5 \% \mathrm{TDN}$, we can observe that the supplementation of ground corn at $0.50 \mathrm{~kg} /$ day and $1.00 \mathrm{~kg} /$ day were averaging NUS within this limit (Table 6).

Values of urinary urea nitrogen (EUNU) indicate that the absolute amount of $\mathrm{N}$ is eliminated without being properly utilized by the animal. We observed a positive linear order effect $(\mathrm{P}<0.10)$ for this variable with increasing levels of corn fed to heifers (Table 6). Such behavior leads to a possible energy demand facing the supply of NPN of corn itself and forage. This inference becomes plausible when it is recalled that the structure of the grain starch is responsible for different rates of rumen fermentation, since the formation of crystal grains differs for species and cultivars of grains, depending on the structure of the amylose and amylopectin that compose them (Van Barneveld, 1999) and especially the protein matrix that limits the access of microorganisms to the starch granules.

\section{Conclusions}

Recreated Zebu steers grazing Brachiaria decumbens during the rainy season respond positively to the supply of low intake energy supplement, since they present more intake of digestible dry matter, digestibility of fibrous carbohydrates and production of microbial nitrogen compounds.

\section{References}

ARROQUY, J.I.; COCHRAN, R.C.; NAGARAJA, T.G. et al. Effect of types of non-fiber carbohydrate on in vitro forage fiber digestion of low-quality grass hay. Animal Feed Science and Technology, v.120, p.93-106, 2005.

ASSOCIATION OF OFFICIAL ANALYTICAL CHEMISTRY - AOAC. Official methods of analysis. 15.ed. Arlington, 1990. 1117p.

BARGO, F.; MULHER, L.D.; KOLVER, E.S. et al. Production and digestion of supplemented dairy cows on pasture. Journal Dairy Science, v.86, p.1-42, 2003.

CHEN, X.B.; GOMES, M.J. Estimation of microbial protein supply to sheep and cattle basid on urinary excretion of purine derivatives-an overview of the technical details. Buchsburnd, Aberdeen: Rowett Research Institute, 1992. $21 \mathrm{p}$. (Ocasional publication).

CHIZZOTTI, M.L.; VALADARES FILHO, S.C.; VALADARES, R.F.D. et al. Consumo, digestibilidade e excreção de uréia e derivados de purinas em novilhas de diferentes pesos. Revista Brasileira de Zootecnia, v.35, p.1813-1821, 2006.

DETMANN, E.; PAULINO, M.F.; CECON, P.R. et al. Níveis de proteína em suplementos para terminação de bovinos em pastejo durante o período de transição seca/águas: Consumo voluntário e trânsito de partículas. Revista Brasileira de Zootecnia v.34, p.1371-1379, 2005

DETMANN, E.; PAULINO, M.F.; ZERVOUDAKIS, J.T. et al. Cromo e indicadores internos na estimação do consumo de novilhos mestiços, suplementados, a pasto. Revista Brasileira de Zootecnia, v.30, n.5, p.1600-1609, 2001a.

DETMANN, E.; PAULINO, M.F.; ZERVOUDAKIS, J.T. et al Suplementação de novilhos mestiços durante a época das águas: parâmetros ingestivos e digestivos. Revista Brasileira de Zootecnia, v.30, n.4, p.1340-1349, 2001b.

EL-SHAZLY, K; DEHORITY, B.A.; JOHSON, R.R. Effect of starch on the digestion of cellulose in vitro and in vivo by rumen microorganisms. Journal of Animal Science, v.20, p.268-273, 1961.

EUCLIDES, V.P.B.; MEDEIROS, S.R. Suplementação animal em pastagens e seu impacto na utilização da pastagem. In: SIMPÓSIO SOBRE MANEJO DAS PASTAGENS, 22., 2005, Piracicaba. Anais... Piracicaba: FEALQ, 2005. p.33-70.

EUCLIDES, V.P.B.; MACEDO, M.C.M.; OLIVEIRA, M.P. Avaliação de diferentes métodos de amostragem (para se estimar o valor nutritivo de forragens) sob pastejo. Revista Brasileira de Zootecnia, v.21, n.2, p.691-702, 1992.

FIESER, B.G.; VANZANT, E.S. Interactions between supplement energy source and tall fescue hay maturity on forage utilization by beef steers. Journal of Animal Science, v.82, p.307-318, 2004.

GOETSCH, A.L.; JOHNSON, Z.B.; GALLOWAY, D.L. et al Relationships of body weight, forage composition, and corn supplementation to feed intake and digestion by Holstein steers calves consuming Bermudagrass hay ad libitum. Journal of Animal Science, v.69, p.2634-2645, 1991.

HALL, M.B.; AKINYODE, A. Cottonseed hulls: working with with a novel fiber source. In: ANNUAL FLORIDA RUMINANT NUTRITION SYMPOSIUM, 11., 2000, Gainesville. Proceedings.. Gainesville, 2000. p.179-186.

LAZZARINI, I.; DETMANN, E.; SAMPAIO, C.B. et al. Intake and digestibility in cattle fed low-quality tropical forage and supplemented with nitrogenous compounds. Revista Brasileira de Zootecnia, v.38, n.10, p.2021-2030, 2009.

LICITRA, G.; HERNANDEZ, T.M.; VAN SOEST, P.J Standardization of procedures for nitrogen fractionation of ruminant feeds. Animal Feed Science and Technology, v.57, p.347-358, 1996.

McMENIMAN, N.P. Methods of estimating intake of grazing animals In: REUNIÃO ANUAL DA SOCIEDADE BRASILEIRA DE 
ZOOTECNIA, 34., 1997, Juiz de Fora. Anais... Juiz de Fora: SBZ, 1997. p.131-168.

MERTENS, D.R. Gravimetric determination of amylase-treated neutral detergent fiber in feeds with refluxing in beakers or crucibles: collaborative study. Journal of AOAC International, v.85, n.6, p.1217-1240, 2002.

MINSON, D.J. Forage in ruminant nutrition. San Diego: Academic Press, 1990. 483p.

MOORE, J.E.; BRANT, M.H.; KUNKLE, W.E. et al. Effects of supplementation on voluntary forage intake, diet digestibility, and animal performance. Journal of Animal Science, v.77, suppl. 2/J, p.122-135, 1999.

MOULD, F.L.; ØRSKOV, E.R.; MANNS, O. Associative effects of mixed feeds. I. Effects of type and level of supplementation and the influence of the rumen $\mathrm{pH}$ on cellulolysis in vivo and dry matter digestion of various roughages. Animal Feed Science and Technology, v.10, p.15-30, 1983.

NATIONAL RESEARCH COUNCIL - NRC. Nutrient requirements of dairy cattle. 7.ed. Washington, DC: National Academic Press, 2001. 381p.

OBARA, Y.; DELLOW, D.W.; NOLAN, J.V. The influence of energyrich supplements on nitrogen kinetics in ruminants. In: TSUDA, T., SASAKI, Y., KAWASHIMA, R. (Eds.) Physiological aspects of digestion and metabolism in ruminants. New York: Academic Press, 1991. p.515-539.

PAULINO, M.F.; DETMANN, E.; VALADARES FILHO. S.C. Suplementação animal em pasto: energética ou protéica? In: SIMPÓSIO SOBRE MANEJO ESTRATÉGICO DA PASTAGEM, 3., 2006, Viçosa, MG. Anais... Viçosa, MG: SIMFOR, 2006. p.359-392.

PAULINO, M.F.; ZERVOUDAKIS, J.T.; MORAES, E.H.B.K. et al. Suplementação múltipla para bovinocultura de ciclo curto em pastagens. In: SIMPÓSIO DE PRODUÇÃO DE GADO DE CORTE, 3., 2002, Viçosa, MG. Anais... Viçosa, MG: SIMCORTE, 2002. p.199-242.

PAULINO, M.F.; DETMANN, E.; ZERVOUDAKIS, J.T. Suplementos múltiplos para recria e engorda de bovinos em pastagens. In: SIMPÓSIO DE PRODUÇÃO DE GADO DE CORTE, 2., 2001, Viçosa, MG. Anais... Viçosa, MG: SIMCORTE, 2001. p.187-233.

POPPI, D.P.; McLENNAN, S.R.; BEDIYE, S. et al. Forage quality: Strategies for increasing nutritive value of forages. In: INTERNATIONAL GRASSLAND CONGRESS, 18., Winnipeg and Saskatoon, 1997. Proceedings... Winnipeg and Saskatoon: Canadian Forage Council, Canadian Society of Agronomy, Canadian Society of Animal Science, 1997. p.307-322.

POPPI, D.P.; McLENNAN, S.R. Protein and energy utilization by ruminants at pasture. Journal of Animal Science, v.73, p.278-290, 1995.

POPPI, D.P.; HUGHES, T.P.; L'HUILLIER, P.J. Intake of pasture by grazing ruminants. In: NICOL, A.M. (Ed.). Livestock feeding on pasture. Hamilton: New Zealand Society of Animal Production, 1987. p.55-64. (Occasional publication, 10).

PORTO, M.O. Suplementos múltiplos para recria e terminação de bovinos em pastejo durante o período das águas. 2005. 99f. Dissertação (Mestrado em Zootecnia) - Universidade Federal de Viçosa, Viçosa, MG.

ROBERTSON, J.B.; VAN SOEST, P.J. The detergent system of analysis and its application to human foods. In: JAMES, W.P.T.; THEANDER, O. (Eds.). The analysis of dietary fiber. New York: Marcell Dekker, 1981. p.138-147.

RUSSELL, J.B.; O'CONNOR, J.D.; FOX, D.J. et al. A net carbohydrate and protein system for evaluating cattle diets: I. Ruminal fermentation. Journal of Animal Science, v.70, p.3551-3561, 1992.

SAMPAIO, C.B. Consumo, digestibilidade e dinâmica ruminal em bovinos alimentados com forragem tropical de baixa qualidade suplementados com compostos nitrogenados. 2007. 53f. Dissertação (Mestrado em Zootecnia) - Universidade Federal de Viçosa, Viçosa, MG.

STATISTICAL ANALYSIS SYSTEM - SAS. SAS user's guide: Statistics Version. Cary: 1990 (CD-ROM).

VALADARES FILHO, S.C.; PAULINO, P.V.R.; DETMANN, E. et al. Exigências nutricionais de zebuínos no Brasil. II. Proteína. In: VALADARES FILHO, S.C.; PAULINO, P.V.R.; MAGALHÃES, K.A. (Eds.) Exigências nutricionais de zebuínos e tabelas de composição de alimentos BR-Corte. Viçosa, MG: Suprema, 2006c. p.75-84.

VALADARES FILHO, S.C.; PINA, D.S.; CHIZZOTTI, M.L. et al. Degradação ruminal da proteína dos alimentos e síntese de proteína microbiana. In: VALADARES FILHO, S.C.; PAULINO, P.V.R.; MAGALHÃES, K.A. (Eds.) Exigências nutricionais de zebuínos e tabelas de composição de alimentos BR-Corte. Viçosa, MG: Suprema, 2006a. p.13-44.

VALADARES FILHO, S.C.; PAULINO, P.V.R.; DETMANN, E. et al Exigências nutricionais de zebuínos no Brasil. I. Energia. In: VALADARES FILHO, S.C.; PAULINO, P.V.R.; MAGALHÃES, K.A. (Eds.) Exigências nutricionais de zebuínos e tabelas de composição de alimentos BR-Corte. Viçosa, MG: Suprema, 2006b. p. 57-74.

VALADARES, R.F.D.; BRODERICK, G.A.; VALADARES FILHO, S.C. et al. Effect of replacing alfalfa silage with high moisture corn on ruminal protein synthesis estimated from excretion of total purine derivatives. Journal of Dairy Science, v.82, p.2686-2696, 1999.

VALADARES, R.F.D.; GONÇALVES, L.C.; SAMPAIO, I.B. et al. Níveis de proteína em dietas de bovinos. 2. Consumo, digestibilidade e balanço de compostos nitrogenados. Revista Brasileira de Zootecnia, v.26, n.6, p.1259-1263, 1997.

Van BARNEVELD, S.L. Chemical and physical characteristics of grains related to variability in energy and amino acid availability I ruminants: a review. Australian Journal of Agricultural Research, v.50, p.651-666, 1999.

VAN SOEST, P.J. Nutritional ecology of the ruminant. 2.ed. Ithaca: Cornell University Press. 1994. 476p.

VERBIC, J.; CHEN, X.B.; MACLEOD, N.A. et al. Excretion of purine derivatives by ruminants. Effect of microbial nucleic acid infusion on purine derivative excretion by steers. Journal of Agricultural Science, v. 114, p.243-248, 1990. 